\title{
The C. elegans Sex-determining Gene fem-2 Encodes a Putative Protein Phosphatase
}

\author{
Dave Pilgrim,* Angela McGregor, Petra Jäckle, Troy Johnson, \\ and Dave Hansen
}

Department of Biological Sciences, University of Alberta, Edmonton, Alberta, Canada T6G 2E9

Submitted June 2, 1995; Accepted June 28, 1995

Monitoring Editor: Judith Kimble

\begin{abstract}
The genetic and molecular analysis of genes involved in the regulation of sex determination in Caenorhabditis elegans suggests that the gene fem-2 plays an important role in regulating a pathway transducing a non-cell-autonomous signal to a nuclear transcription factor. The wild-type fem-2 gene was cloned by identifying sequences from the $C$. elegans physical map that could restore normal Fem-2 function to homozygous mutant fem-2 transgenic animals. cDNA sequences mapping to the minimal rescuing region correspond to an open reading frame with a sequence similar to protein phosphatase $2 \mathrm{C}$ enzymes from systems as diverse as yeast, humans, and plants, but the alignments suggest that FEM-2 falls into a separate class of proteins than the canonical homologues. Several fem-2 mutant alleles were sequenced, and the mutations are predicted to cause protein changes consistent with their observed phenotypes, such as missense mutations in conditional alleles, and a nonsense mutation in a predicted null allele. This is the first evidence implicating phosphorylation and/or dephosphorylation as a control mechanism in C. elegans sex determination
\end{abstract}

\section{INTRODUCTION}

The primary sex-determining signal in the nematode Caenorhabditis elegans is the ratio of sex chromosomes (X) to autosomes (A) (Nigon, 1951). Males have a single $\mathbf{X}$ chromosome per diploid cell $(\mathbf{X} / \mathbf{A}$ ratio of $0.5)$ while hermaphrodites have two (X/A ratio of 1.0). The latter may be thought of as females that express a transient male phase (spermatogenesis) in their germ line before switching to the exclusive production of oocytes. Mutations have been isolated in C. elegans that cause animals to ignore the $\mathbf{X} / \mathbf{A}$ ratio. Loss-offunction mutations in the fem-1, -2 , or -3 (feminization) genes cause $X X$ and $X 0$ animals to develop as females (the mutant hermaphrodites lose the ability to make sperm), while loss-of-function mutations in any of the three tra (transformer) genes cause $\mathrm{XX}$ animals to be masculinized. A genetic epistasis pathway has been proposed by Hodgkin using these, and other mutants, in which somatic sex determination in C. elegans is controlled by a hierarchy of negative regulatory interactions (Hodgkin, 1980, 1987), culminating in the gene

\footnotetext{
* Corresponding author.
}

tra-1 (Figure 1). The genetic regulation of germline sex determination in $C$. elegans involves these, as well as germline specific genes (reviewed by Clifford et al., 1994). Several genes linking the X/A ratio with both dosage compensation and sex determination have also been characterized (Villeneuve and Meyer, 1987; Miller et al., 1988; Nusbaum and Meyer, 1989; DeLong et al., 1993).

The fem genes have a central role in two decisions during development of $C$. elegans: whether to develop somatically as a male or female, and whether to make sperm or oocytes in the germ line (Kimble et al., 1984; Hodgkin, 1986). Homozygous mutant alleles of the fem genes result in feminization of the animal, regardless of the karyotypic sex, implying that the wild-type function is to promote male development. Genetic evidence suggests that the fems act both as positive regulators of male germ cell development and as negative regulators of tra-1, a gene that promotes female somatic development. The fem gene products must be active in the male germ line and soma, and transiently active in the XX (hermaphrodite) germ line. The fem genes have been shown to be under different temporal control in the germ line and soma (Doniach and 
A

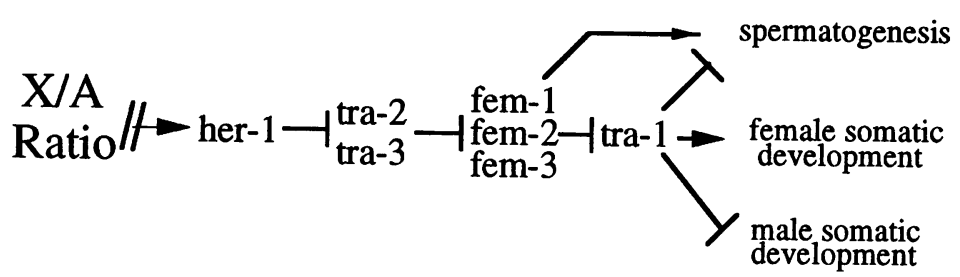

B

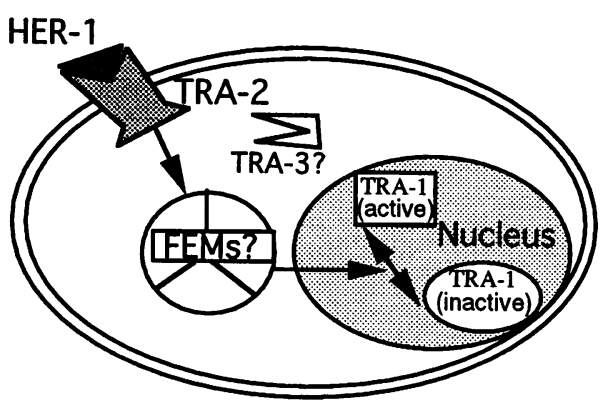

Figure 1. (A) Model of genetic interactions between the genes involved in somatic and germline sex determination in C. elegans. Only the genes downstream of her-1 are illustrated, and genes affecting only the sex determination of the germ line (e.g. fog and mog-1 genes [Schedl and Kimble, 1988; Graham and Kimble, 1993; Evans et al., 1992]) have been omitted. Arrows indicate positive interactions, and bars indicate negative or repressive interactions. Adapted from Hodgkin, 1992. (B) Model for molecular interactions in the determination of somatic sex in C. elegans. Only gene products corresponding to the model in panel A are illustrated. See text for details. Adapted from Kuwabara and Kimble, 1992.
Hodgkin, 1984; Kimble et al., 1984; Hodgkin, 1986), presumably due to negative regulation by the genes tra-2 and tra-3. The activities of tra-2 and tra-3 are in turn repressed by her-1. Several of the genes in the pathway, including fem-2, demonstrate maternal rescue of the mutant phenotype (Doniach and Hodgkin, 1984; Kimble et al., 1984), suggesting that either the mRNA or gene product is inherited through the female germ line. Because the fem genes act to promote male development, there must be control against inappropriate activity in XX animals. In contrast to Drosophila, where control of sex determination occurs at the level of mRNA splicing (reviewed in Hodgkin, 1990), evidence from C. elegans suggests control at both the transcriptional and translational levels (Doniach and Hodgkin, 1984; Rosenquist and Kimble, 1988; Evans et al., 1992).

The genetic epistasis together with the molecular analyses of the genes have suggested that the cellular regulation of somatic sex determination in C. elegans involves a signal transduction pathway (Figure 1; reviewed by Kuwabara and Kimble, 1992) with control mechanisms that differ from other sex determination systems (Hodgkin, 1992). The tra-1 and -2 , fem-1 and -3 , and her-1 genes have been cloned and characterized. HER-1 is predicted to be a secreted protein that acts non-cell autonomously (Hunter and Wood, 1992; Perry et al., 1993). TRA-2 has the characteristics of a transmembrane receptor, possibly for HER-1 (Kuwabara et al., 1992). The FEM-1 protein contains an ankyrin motif, suggesting that it is involved in protein-protein interaction (Spence et al., 1990), whereas the predicted FEM-3 sequence is novel (Ahringer $e$ t al., 1992). TRA-1 contains a zinc-finger DNA-binding domain and is probably a transcriptional regulator
(Zarkower and Hodgkin, 1992). A complete molecular description of the pathway awaits characterization of the fem-2 gene product.

Alignment of the physical and genetic maps of $C$. elegans on the left end of Linkage Group III (Pilgrim, 1993) predicted the physical position of the fem-2 gene. In this work, we describe how this has permitted transformation rescue of the fem- 2 mutant phenotype using clones selected from this genomic region. The DNA sequence of the rescuing region predicts a single open reading frame (ORF). It is likely that this sequence encodes fem-2, because mutant fem-2 alleles show single basepair (bp) changes consistent with a defect in the predicted FEM-2 protein. This protein shows sequence similarity to several proteins involved in the regulation of signal transduction pathways. The two proteins most similar to FEM-2 are ABI1, a protein phosphatase from plants involved in mediating hormone response, and a protein of unknown function from humans. The sequence similarities suggest that FEM-2 may have protein phosphatase activity and that $C$. elegans sex determination may be regulated by a kinase/phosphatase cascade.

\section{MATERIALS AND METHODS}

\section{Strains and Genetics}

Nematode stocks were maintained and handled as described by Wood (1988). The strains used (Table 1) were maintained at $20^{\circ} \mathrm{C}$, except where indicated. The isolation and characterization of some of the fem-2 alleles used in this work are described by Kimble et al. (1984) and Hodgkin (1986). XO animals were isolated from strains carrying the him- 8 mutation, which produces a high incidence of males due to $\mathbf{X}$-chromosome nondisjunction (Hodgkin and Brenner, 1977; Broverman and Meneely, 1994). Two putative deficiencies (Df) for the fem- 2 region have been generously shared in advance of 
Table 1. C. elegans strains used in this work

\begin{tabular}{|c|c|}
\hline Strain genotype & Source \\
\hline $\begin{array}{l}\text { fem-2(b245ts) } \\
\text { fem-2(q117ts) } \\
\text { fem-2(b245ts); him-8(e1489) } \\
\text { fem-2(b245e2005); tra-3(e1767) } \\
\text { unc-45(r450ts) sDf124(s2670) + } \\
\text { sC1(s2073)[++dpy-1(s2171)] }\end{array}$ & $\begin{array}{l}\text { J. Hodgkin } \\
\text { J. Kimble } \\
\text { J. Hodgkin } \\
\text { J. Hodgkin }{ }^{\mathrm{a}} \\
\text { H. Stewart and } \\
\text { D. Baillie }\end{array}$ \\
\hline$w c D f 1(w c 5)++d p y-1(e 1)$ & L. Venolia \\
\hline $\begin{array}{l}+ \text { daf-7(e1372) par-2(e2030) + } \\
\text { unc-45(r450ts) sDf124(s2670) +; him-8(e1489) }\end{array}$ & This laboratory \\
\hline $\begin{array}{ll}s C 1(s 2073)[++d p y-1(s 2171)] & \text { him-8(e1489) } \\
\text { fem-2(e2105) }+ & ; \text { him-8(e1489) }\end{array}$ & This laboratory ${ }^{a}$ \\
\hline $\begin{array}{lcc}s C 1(s 2073)[+d p y-1(s 2171)] & \text { him-8(e1489) } \\
\text { fem-2(e210n }) & + & \end{array}$ & $\mathrm{n}=1$ to 6 \\
\hline$s C 1(s 2073)[+d p y-1(s 2171)]$ & This laboratory ${ }^{a}$ \\
\hline
\end{tabular}

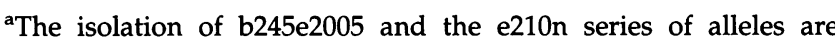
described in Hodgkin, 1986.

publication by H. Stewart and D. Baillie $(s D f 124)$ and L. Venolia [wcDf1].

$\mathrm{XO}$ animals hemizygous for fem-2 mutant alleles were generated as follows: $\mathrm{fem} /+$ males crossed to $\mathrm{fem} / \mathrm{Df}$ females, or $D \mathrm{f} /+$ males crossed to $\mathrm{fem} / \mathrm{fem}$ females. No difference was seen in the phenotype of the $\mathrm{XO}$ animals prepared by these two methods. Homozygous $\mathrm{fem} / \mathrm{fem} \mathrm{XO}$ animals were produced among the self progeny of fem-2(e2105); him-8(e1489) maternally rescued hermaphrodites. The progeny were raised at 15,20 , or $25^{\circ} \mathrm{C}$.

\section{Nematode Transformation}

Adult hermaphrodites, homozygous for fem-2(b245ts), were raised at $20^{\circ} \mathrm{C}$ and were transformed with cloned DNA, using microinjection as described by Mello et al. (1991). The animals were injected with a mixture of the pRF4 plasmid, containing a dominant allele of the rol-6 gene, su1006 dm (Mello et al., 1991) and the test DNA. The pRF4 plasmid causes the animals to adopt a dominant characteristic rolling motion on the plates, and serves as a positive control for transformation. Following injection, the hermaphrodites were incubated at the restrictive temperature of $25^{\circ} \mathrm{C}$, unless indicated. Progeny from the injected animals were raised at $25^{\circ} \mathrm{C}$, and examined 3 to 4 days later, for the Rol-6 phenotype, as well as for self-fertility. Uninjected fem-2(b245ts) animals, or animals injected with pRF4 alone produce an $\mathrm{F} 1$ brood at $25^{\circ} \mathrm{C}$ consisting exclusively of selfsterile females. In some experiments, the injected hermaphrodite was kept at $20^{\circ} \mathrm{C}$, and lines that transmit the transgene were selected by following the Rol- 6 phenotype alone. The transgenic lines were subsequently tested for rescue of the fem-2(b245) XX phenotype at $25^{\circ} \mathrm{C}$. The number of transgenic animals scored varied from injection to injection and clone to clone, but at least two independent transmitting lines were assayed for each of the rescuing clones described in the text. For the clones that are classed as "failure to rescue," three to ten F1 Rol-6 animals were examined at the restrictive temperature. Only representative clones are discussed in the text. In addition to these, other clones have also been tested for their ability to rescue the fem-2 mutant phenotype. The only clones that have shown rescue are those that include at least the minimal rescuing region.
Once the minimum rescuing region had been defined by the suppression of the b245ts XX germline defect, the DP\#DBP026 and DP\#DBP141 plasmids were tested for their ability to rescue the $X X$ germline and $\mathrm{XO}$ germline and soma defects at 20 and $25^{\circ} \mathrm{C}$. Heterozygous animals of the strain fem-2(e2105) $+/ s C 1[+d p y-1(s 2171)]$; him-8(e1489) were injected with the test and rol-6 plasmids as described above. Transmitting lines were established at $20^{\circ} \mathrm{C}$. Homozygous fem-2(e2105); him-8 animals were selected from the progeny, and these were shown to produce both self-fertile $\mathrm{XX}$ animals and somatically normal males (XO) at $25^{\circ} \mathrm{C}$. XO mating ability was scored by placing several Rol- $6 \mathrm{XO}$ animals (which had been raised at $25^{\circ} \mathrm{C}$ ) on a plate with four $u n c-45(r 450 t s)$ hermaphrodites, and screening the F1 brood for non-Unc rolling males. (Several males were used because the extrachromosomal arrays are not completely meiotically or mitotically stable, and can produce mosaic progeny, and also because of the poor mating efficiency of rol-6 males). For each of the plasmids, two independent matings produced outcross progeny, indicating that at least some of the fem-2(e2105) XO animals were completely rescued by the transgenes at $25^{\circ} \mathrm{C}$.

\section{DNA Analysis}

DNA manipulation was as described in Pilgrim (1993) except where otherwise stated. DNA fragments were subcloned from cosmid and lambda genomic clones into pBluescript (Stratagene, La Jolla, CA). All clones were sequenced using a Sequenase v2.0 DNA sequencing kit (United States Biochemical, Cleveland, $\mathrm{OH}$ ) as described by the manufacturer.

\section{PCR Analysis}

The presence of the test DNA in some, but not all, transgenic lines was assayed using DNA amplification by the polymerase chain reaction (PCR). Single worm PCR analysis was performed as described by Williams et al. (1992) and Pilgrim and Bell (1993). Confirmation of the $5^{\prime}$ end of the fem-2 transcript used the rapid amplification of cDNA ends (RACE) technique (Frohman et al., 1988) with a Life Technologies (Gaithersburg, MD) 5' RACE kit, following the directions of the manufacturer. The primer DHA9 (Table 2) was used for first strand synthesis, and AMC1 was used for PCR amplification. The RACE product was cloned into the vector PGEM-T (Promega, Madison, WI) before sequencing.

The deletion of at least part of the fem-2 locus by the deficiency $s D f 124$ was noticed by D. Collins and H. Stewart (personal communication) and confirmed in our lab. Heterozygous $s D f 124 /+$ hermaphrodites were placed on a plate and allowed to lay eggs for 24 $h$ at $20^{\circ} \mathrm{C}$. The adults were removed, and after a further $24 \mathrm{~h}$, unhatched embryos were picked for PCR analysis. Embryos were picked from wild-type worms as a control. DNA from single embryos was prepared for PCR as described (Williams et al., 1992). Primers DHA4, DHA17, DHA19, and SAD2 (Table 2) were used to test for DNA at the fem-2 locus, while primers MMA1 and MMA2, which amplify DNA near the unc-119 locus on the right end of Linkage group III (M. Maduro and D.P., unpublished data) were used as positive controls. A similar analysis was performed for the $w c D f 1$ deficiency.

DNA from the mutant alleles of fem-2 was amplified as follows: for $b 245 t s$ and $q 117 t s$, homozygous strains were grown at $20^{\circ} \mathrm{C}$, and genomic DNA was isolated as described in Pilgrim (1993). For e2103 and $e 2105$, individual L4 hermaphrodites (either $\mathrm{fem} /+$ or $\mathrm{fem} / \mathrm{fem}$, which are indistinguishable) from a fem-2/+ mother were set up on a plate at $20^{\circ} \mathrm{C}$ and allowed to produce an F1 brood. Six animals were selected from broods that consisted entirely of female adults ( fem-2/fem-2), combined in one tube, and prepared as for the single worm PCR method described above. A portion of the DNA was amplified by PCR using the primers DHA3 and DHA4, and cloned into the pGEM-T (Promega) vector. For each mutant allele, clones from at least three independent PCR reactions were sequenced. For $e 2101, e 2102, e 2104, e 2106$, and b245e2005, genomic DNA was am- 
D. Pilgrim et al.

Table 2. PCR primers used in this work

\begin{tabular}{llr}
\hline Primer & Sequence $\left(5^{\prime}\right.$ to $\left.3^{\prime}\right)$ & $\begin{array}{c}\text { Position in } \\
\text { fem-2 sequence }\end{array}$ \\
\hline AMC1 & ACCTCGACGTCATAGCTAGT & 464 \\
DHA3 & CAAAGATCTTGTCCCACCGAAGCCGGTAGTGG & 278 \\
DHA4 & CGGTCTAGATGACGACGATATGGTGGATAG & 2632 \\
DHA9 & CGTCTAGAAGCTCCAGCGAGCTTGCGAAGC & 1524 \\
DHA17 & CCGAGCACTCGGAGATGTTC & 1837 \\
DHA19 & CGATGGTCACGGTGGTCACGAG & 1437 \\
SAD2 & AGAAATTCCATCACAAGCCAG & 1912 \\
MMA1 & AGTCGGCCTTATTTGCATTAC & n/a \\
MMA2 & AAATTGCATGCCAGCACCGGTC & n/a \\
\hline
\end{tabular}

aNumber refers to Figure 3, and most 3' base in primer.

plified by PCR using the primers described above, and the PCR product was directly used as the template for sequencing.

\section{cDNA Isolation and Analysis}

A cDNA library, prepared from mixed stage C. elegans RNA and cloned into the $\lambda$ Zap vector (Barstead and Waterston, 1989) was screened with a genomic DNA probe (15-kbp XbaI fragment containing sequences shown in Figure 2). From approximately $10^{5}$ recombinant phage screened, 43 positive plaques were isolated. Subsequent characterization of the clones suggested that one-third came from within the 15-kb genomic region, but from outside the minimal rescuing region. Ten cDNA clones that fell entirely within the rescuing region were sequenced. One of the cDNA clones was chimeric, having been ligated to a second, unrelated cDNA. cDNA clones were excised in vivo to produce pBluescript $\mathrm{SK}(-)$ phagemid containing the cloned insert as described by the supplier (Stratagene).

\section{Construction of Minigene}

A partial minigene was constructed by ligating a $1.5-\mathrm{kb}$ SalI DNA fragment from a cDNA (containing part of exon 2 to the $3^{\prime}$ end of the cDNA, including the poly(A) tail and a portion of the polylinker) into a Bluescript plasmid containing 2.5-kb of upstream genomic sequence (XhoI-SalI fragment) as well as exon 1, the first 56-bp intron, and part of exon 2 . The cDNA fragment was cloned into both the sense and antisense orientations. The ability of the minigene to rescue the fem-2(b245ts) and fem-2(e2105) mutant phenotypes was tested as described above.

\section{RNA Isolation and Characterization}

Nematodes from N2 (XX) or him-8(e1489) (XX and XO) strains were grown in liquid cultures (mixed-stage or synchronized cultures) and purified according to Wood et al. (1988). Nematode pellets were then flash frozen in liquid nitrogen and stored at $-80^{\circ} \mathrm{C}$. RNA was isolated using glass bead homogenization as described by Hope (1994) and Johnson, Simpson, and Pilgrim (unpublished data). For embryos, RNA was prepared by grinding the frozen pellets with a mortar and pestle in liquid nitrogen. Northern analysis was performed using $1 \%$ agarose gels containing formaldehyde as described (Sambrook et al., 1989). Radiolabelled antisense RNA probes were synthesized using T7 or T3 RNA polymerases as directed by the manufacturer (Promega), using a linearized cDNA clone as a template.

\section{RESULTS}

An alignment of the physical and genetic maps for the left end of C. elegans Linkage Group III (Pilgrim, 1993) suggested a molecular position for fem-2. The fem-2 mutant alleles mapped between two RFLPs, eP95 and $e P 64$, which is a region of the physical map (approximately 0.2 map units or $50 \mathrm{kbp}$ between the RFLPs; Pilgrim, 1993) that is completely covered by yeast artificial chromosome and cosmid clones from the $C$. elegans physical mapping project (Coulson et al., 1986-

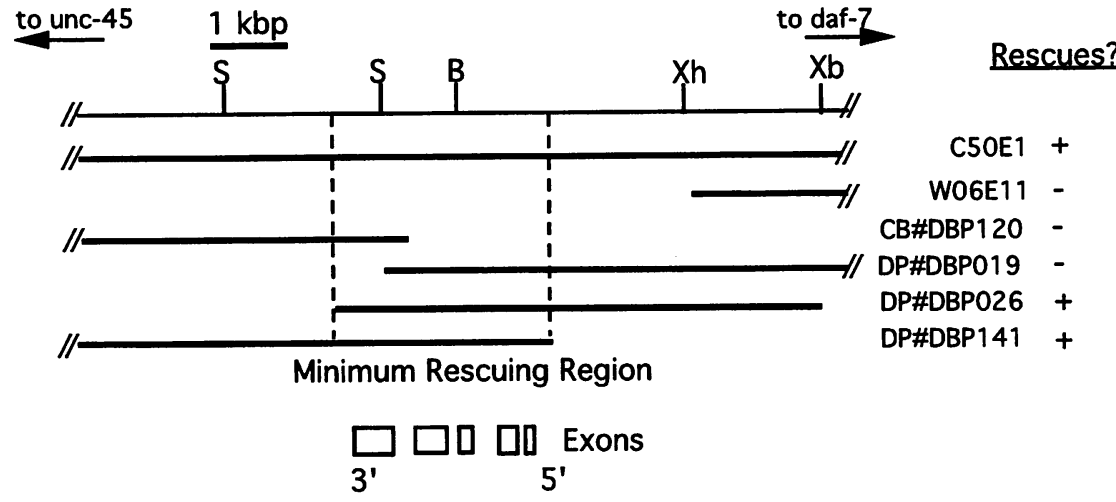


1991), as well as lambda clones identified by crosshybridization to the yeast artificial chromosomes (Pilgrim, 1993). Cloned DNA fragments from this region of the physical map were tested for their ability to rescue the fem-2 mutant phenotype, following germline transformation. The easiest fem-2(b245ts) mutant phenotype to score is the self-sterility of $\mathrm{XX}$ animals (females) at the restrictive temperature, due to their lack of spermatogenesis. Rescue was assayed by the restoration of self-fertility to homozygous fem-2(b245ts) transgenic animals at $25^{\circ} \mathrm{C}$.

Three overlapping cosmid clones and one lambda clone were each able to restore spermatogenesis to transgenic animals raised at the nonpermissive temperature (Figure 2), while flanking cosmid and lambda clones failed to rescue. Transmitting lines were established with all of the rescuing clones, and several lines have been stably maintained for over 100 generations. The transgene is thought to be present as a meiotically unstable extrachromosomal array (Mello et al., 1991) that is only passed to a fraction of the progeny. Animals that fail to inherit the array produce sterile progeny at the restrictive temperature. The rescuing region has subsequently been narrowed to $3.0 \mathrm{kbp}$, and its boundaries are defined by the ends of the subclones DP\#DBP026 and DP\#DBP141 (Figure 2). Clones containing less than this minimal region of genomic DNA fail to rescue. A subset of the rescuing clones have been successfully tested for XX germline rescue of a second temperature-sensitive allele $q 117 \mathrm{ts}$, and a putative null allele $e 2105$, both at $25^{\circ} \mathrm{C}$.

The two minimal subclones DP\#DBP026 and DP\#DBP141 were then tested for their ability to rescue the fem-2(e2105) XO somatic and germline feminization at $25^{\circ} \mathrm{C}$. At this temperature, fem-2(e2105) $\mathrm{XO}$ progeny of homozygous mothers develop as fertile females (Hodgkin, 1986). However, if they also carry either of the two plasmids as extrachromosomal arrays, the $\mathrm{XO}$ animals are somatically normal males, and are fertile when outcrossed (MATERIALS AND METHODS). Therefore, this confirms that the minimum rescuing region has been defined for both the somatic and germline phenotypes, in XX and $X O$ animals, at all temperatures.

A 15-kbp genomic DNA fragment, which included the minimal rescuing region, was used to screen a mixed-stage cDNA library (Barstead and Waterston, 1989). Ten of the clones that mapped to the minimal rescuing region were characterized. Even though the small size and high $\mathrm{A}+\mathrm{T}$ content of $C$. elegans introns (Wood et al., 1988) allow the prediction of the position of exons within the genomic sequence; the intron/ exon boundaries as well as the $5^{\prime}$ and $3^{\prime}$ ends of the gene were confirmed by sequencing the cDNAs. All clones were consistent with a single splicing pattern (see Figures 2 and 3), and were completely contained within the rescuing region. Both cDNA and genomic DNA sequences are given in Figure 3.

None of the cDNAs selected from the library were full length, although three extended into an apparent nematode spliced leader (SL1) sequence at the $5^{\prime}$ end and, therefore, contained all exons from the fem-2 locus. The longest of the cDNA clones contained 9 bases at the $5^{\prime}$ end that matched the last bases of the SL1 sequence (Krause and Hirsh, 1987). The $5^{\prime}$ terminal segment was cloned using the PCR-based RACE procedure (Frohman et al., 1988). Sequence analysis of the cloned RACE product confirmed that the SL1 leader is trans-spliced onto the fem- 2 mRNA. The $5^{\prime}$ end of the minimal rescuing region lies only $240 \mathrm{bp}$ upstream of the spliced leader acceptor site. Because the transformation rescue assay for fem- 2 function produces multicopy transgenic arrays (Mello et al., 1991), a basal level of transcription from each gene may prove sufficient to rescue, and therefore this small region may not contain all sequences responsible for wild-type fem-2 transcriptional expression or regulation. The genomic and cDNA sequences are consistent with the presence of a single transcribed species, and a single transcript of the predicted size $(1.8 \mathrm{~kb})$ is seen on Northern blots (Figure 4). The developmental profile of the fem- 2 mRNA suggests that it is detectable at all stages of development, but is most abundant during adult development. When RNA prepared from cultures containing one-third $\mathrm{XO}$ animals is examined, no difference in the transcript patterns has been detected in embryos or adults (Figure 4 and our unpublished results). If there is a transcript from the fem-2 locus that is specific to XO animals, it is either of low abundance, or co-migrates with the 1.8-kb transcript.

To further confirm that the cDNAs correspond to the fem-2 locus, a minigene lacking all introns except the first was tested for its rescuing ability. The chimeric plasmids were constructed by fusing a genomic fragment containing $2.5 \mathrm{kbp}$ of the upstream sequence, exon 1, intron 1, and part of exon 2 to a fragment from a cDNA clone containing the remainder of the exons and the poly(A) tail. In one chimera, the cDNA fragment was inserted in the "sense" orientation relative to the upstream region. In a second plasmid, the cDNA fragment was cloned in the "antisense" orientation. When transgenic lines were generated from the two chimeras, only the clone in the sense orientation was able to rescue the $\mathrm{XX}$ phenotype of fem-2(b245ts) at $25^{\circ} \mathrm{C}$. The same sense clone is able to rescue the $\mathrm{XO}$ somatic and germline feminization of the $e 2105$ allele at $25^{\circ} \mathrm{C}$, suggesting that no other transcript is necessary in XO animals. The second intron is almost completely composed of 12 repeats of a degenerate 30- to 35-bp sequence, itself an inverted repeat. Because this intron sequence can be removed with no apparent effect on the gene function, its role, if any, remains obscure. 
D. Pilgrim et al.

tttttgatccattttgatttgataaaaatgttattaatacaatacaatgcgaattaaattaatatttcgcgcgagaaacgcgcaacgcaccgaaagtgc gcaaacgagaagctttgcgcgtttctggtgcagaaaattctgcattattttttgttgattttcctcattttgtgttgaaatccattgttttttctcgg

tetttctctgatt tt atgttagaacaltattgaatgtcagATCAACCCAGCTGTCCCACCGAAGCCCGTAGTGGTTTPAAACTCGAAAAATAC

GlyAspArgArgArgSerValArgSerLeuLeuGluGluAlaPheAlaAspGluMetGluLysThrSerTyrAspValGluValAlaAspThrProGlnP GGCGATCGCCGTCGAAGTGTCCGGTCACTTCTGGAGGAGGCATTTGCAGATGAAATGGAGAAAACTAGCTATGACGTCGAGGTTGCCGACACTCCACAAC

roHisIleProIleArgPheArgHisProProIleAlaGlyProValHisAspVal PheGlyAspAlaIleHisAspIlePheGlnLysMetMetLysAr CGCATATTCCAATACGTTTCCGTCATCCACCAATCGCCGGACCAGTTCATGATGTTTTCGGAGACGCGATTCACGACATTTTCCAGAAAATGATGAAAAG

gGlyGlnAlaValAspPheCysHisTrpVal SerHisLeuIleAlaThrGluIleAspgluLysPheSerGluValAlaPheArgAspValGlnTyrAsn AGGCCAGGCGGTCGACTTTTGTCACTGGGTGTCTCACTTGATCGCCACAGAAATTGACGAGAAATTCAGTGAAGTTGCGTTCAGAGATGTTCAGTATAAT

ProAspIleTyrValThrAspSerThrThrG

CCTGATATTTATGTTACCGATAGTACCACAGgtaattattaaatgtgcaaaatctgctattaatttagcagaccaagcatgggcctgctaaatattcagc aggcctatccccattggtctgctaaatatttagcatacctaacttgggtctgctaaatatttagcagaccatcccottggtctgctaattatttagcag accaactatgggtctgctaattatttagcagaccacctatgggtctgctaaatatttagcatacctaccatgagtctgctaaatatt cctcattggtctgctaaatattttagctggccattcccouttgatctgctaattttgcaaaataaacttgttaaatagaatttt

luAlaLysLysLeuPheAsnAspLysIleTrpProAlaIleAspLysIleLeuGlngl aaaactcaacact tctgttcatcaatacaacttattt cagAAGCCAAAAAGCTATTCAACGACAAAATTTGGCCGGCGATCGACAAGATTCTCCAGCA

q117 ג

e2102 T

nAsnAlaGluThrCysProIleLeuSerGluLysTrpSerGlyIleHisVal SerGlyAspGlnLeuLysGlyGlnArgHisLysGlnGluAspArgPhe AAACGCCGAAACGTGCCCGATTCTGTCTGAAAAGTGGTCTGGAATCCACGTGTCGGGCGATCAACTGAAAGGGCAACGTCACAAGCAAGAAGATCGGTTT

LeUAlaTyrProAsnGlYGlnTyrMetAspArgGlyGlu

AspProIlese

TTGGCGTATCCTAATGGGCAATATATGGATCGTGGAGAGgtttaggaggattttaggectggaaaattactgaaaaatgaaatt t tagGATCCAATTTC e2005 ג

rValLeUAlaVal PheAspGlyHisGlYGlyHisGluCysSerGlnTYrAlaAlaGlyHisLeuTrpGluThrTrpLeuGluValArgLYsSerArgAsp GGTGTTAGCGGTGTTCGATGGTCACGGTGGTCACGAGTGCTCTCAGTACGCAGCCGGGCACCTTTGGGAGACATGGTTGGAGGTTCGAAAATCGCGAGAT

ProSerAspSerLeuGluAspGlnLeuArgLysSerLeuGluLeuLeuAspGluArgMetThrValArgSerValLysGluCysTrpLysGlyGlySerT CCTTCAGATAGCCTCGAAGATCAGCTTCGCAAGTCGCTGGAGCTTCTCGACGAACGAATGACTGTCAGAAGTGTGAAAGAGTGTTGGAAGGGTGAAGTA

hrAlaValCysCysAlaIleAspMetAspGlnLysLeuMetAlaLeuAlaTrpLeuGlyAspSerProGlyTyrValMetSerAsnIleGluPheArgGl CAGCTGTCTGCTGTGCAATCGACATGGATCAGAAGCTTATGGCGCTGGCGTGGCTCGGTGACTCACCCGGATACGTCATGTCGAACATTGAATTCCGTCA

nLeuThrArgGlYHisSerProSerAspGluArgGluAlaArgArgValGluGluAlaGlyGlyGlnLeuPheValIleGlYGlYGluLeuArgValAsn GTTGACACGTGGACACTCGCCATCCGATGAACGGGAAGCTCGGCGTGTTGAGGAAGCTGGCGGCCAGCTWTTTGTGATTGGAGGCGAATTGCGGGTGAAC

b245 $\boldsymbol{x}$

GlyVal LeuAsnLeuThrArgAlaLeuGlyAspVal ProGlyArgProMetIleSerAsngluProGluThrCysGlnValProIleGluSerSerAspT GGAGTTCTAAATCTCACCCGAGCACTCGGAGATGTTCCTGGACGGCCGATGATCTCTAATGAACCGGAAACGTGTCAGGTGCCTATTGAAAGCTCGGATT

YrLeuValLeuLeuAlaCysAspGlyIleSerAspVal PheAsnGluArgASpLeuTyrGlnLeuValGluAlaPheAlaAsnAspTyrProValG1uA ATCTGGTGCTCCTGGCTTGTGATGGAATTTCTGATGTTTTCAACGAGCGTGACCTGTACCAGTTGGTGGAGGCATTTGCGAATGATTATCCTGTTGAAGg ttaataaaaattcttggagaaaaactaaatttccaaagccaaaaactattttttcgtttttttttctgaaaaaatcagaagattggctatttctcggg ggttttcaaaaaaaaagtaaagattttcgaattattgtatttttaaaaagaaaatcgtgaatttactaaaatttgaaaaaatcaattttaaaaa

TYrAl agluLeuSerArgPheIleCysThrLysAlaIleGluAlaglySerAlaAspAsnValserValValI leGlyPheLeuArgProProGlnAspV TACGCGGAGCTCTCCCGTTTCATCTGTACAAAAGCGATTGAGGCTGGAAGTGCCGACAACGTGTCTGTTGTGATTGGCTTTTTGCGTCCACCGCAGGATG

alTrpLysLeuMetLysHisGluSerAspAspGluAspSerAspValThrAspGluGlu* * *

TGTGGAAGCTTATGAAACATGAATCAGACGATGAAGATTCCGATGTCACTGATGAGGAATAACTGCTTTTCGGTGGAAATTTTGCCTGAAAATTGGGAAA ATTCTTGCTAAACTTCGGTTGATTTTCTCAAATTTTTGTCGTTTT"ITTCCTAATTTTCGGTCGATTTTATCAAATTTTCCCCTGTTTTCCTGTGTCTAT TTGTTTTTGGTATTCCAATTTCTCTCTCCTATTCACCATATCGTCGTCATTTCTCCCCGTTATCTAGCAGCTTTCCGTGACCCACACACATATTTTT GTTCTCGGTGTTCCTGTAGCATTTCACATTTACATACGTTTCCAACCAGTTGGCATCCCACCAAAAATCCGAGTACTTTCCTTCTCCTCCTCCACTTGAA CATATATTTGATTTAATTTATTTTATGATATAAATTGTATAATGACGTGGAAttactgggatattgagtagctgaataggtt tgagacacttt gaca

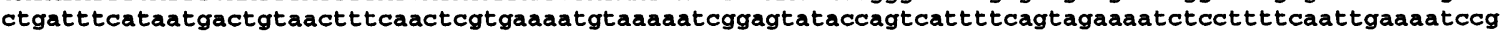
ggatttttcgaaagaaaggctcgaaaacaccgcgaaaaaatgattaaaaaagtcatattttcaagagggaatttcaaatttcccgcttaca

Figure 3. DNA sequence of the minimal rescuing region of the fem-2 gene. Exons are shown in capital letters, introns and flanking regions are shown in lower case. Numbers refer to nucleotides of genomic DNA from the beginning of the rescuing region. Predicted translation is given above the sequence, and the predicted initiation codon is underlined. The DNA changes in the $b 245, q 117, e 2102$, and predicted $e 2005$ mutant alleles are indicated in boldface above the protein sequence. The 22005 mutation is inferred from the sequencing of the doubly mutant b245e2005 allele as described in the text. GenBank accession number for this sequence is U29515. 
A

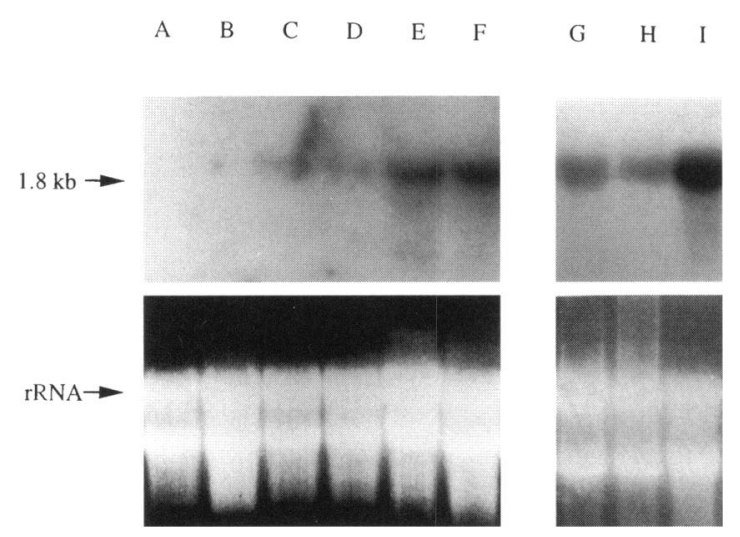

Figure 4. Northern blot of total C. elegans RNA. Fifteen micrograms of total RNA, prepared from wild-type hermaphrodite (lanes A-G and I) or him-8(e1489) XX and XO (lane H) worms synchronized at each developmental stage (embryo, first to fourth larval [L] stages, and adult), was loaded in each lane. Following electrophoresis and capillary transfer, the blot was hybridized to an antisense riboprobe prepared from a fem-2 cDNA clone. The top panel shows the resulting autoradiogram. The bottom panel shows the ethidium bromide-stained gel before Northern transfer to show relative loading. Lanes $A, G$, and $H$ are embryo RNA. Lane B is $L 1, C$ is $L 2, D$ is L3, E is L4, and F and I are adult RNA. The blot in panel B was hybridized with a probe of higher specific activity than the blot in panel A to allow more sensitive detection of the embryonic mRNA.

The sequence of the cDNAs representing the fem-2 transcript is shown in Figure 3. Assuming that the first in-frame ATG sequence corresponds to the initiator methionine, the single open reading frame encodes a protein of 449 amino acids. In a BLAST search of the protein sequence databases (Altschul et al., 1990), six separate regions of the potential FEM-2 protein (conserved motifs I-VI in Figure 5) show significant similarity to an uncharacterized ORF from humans, as well as several mammalian and yeast protein phosphatase 2C (PP2C) genes (Figure 5). In addition, the ABI1 gene from the plant Arabidopsis thaliana, which is involved in regulation of the plant cell's response to abscisic acid (Leung et al., 1994; Meyer et al., 1994), also shows similarity over the same regions. A second Arabidopsis phosphatase, KAPP (Stone et al., 1994), also shows similarity to FEM-2, but at a lower level. When comparing the predicted amino acid sequence of FEM-2 with that of the other proteins over the six motifs, the human ORF is $37 \%$ identical and $56 \%$ similar over 190 amino acids, rat PP2C is $37 \%$ identical and $49 \%$ similar over 181 amino acids, and ABI 1 is $31 \%$ identical and $46 \%$ similar over 189 amino acids.

The amino terminal third of the predicted FEM-2 protein showed no significant similarity to any sequence in the database, as judged by the BLAST program. Most of the "classical" PP2C proteins have short (30-40 amino acids) amino terminal regions proximal to motif I. In contrast, FEM-2, ABI1, and the human ORF have much larger amino terminal regions, extending 135-170 residues amino terminal to motif I (Figure 5). The amino terminal domains of the three proteins have no significant sequence alignment with one another, although all are rich in charged amino acids and proline. FEM-2 also shows protein sequence similarity to another predicted $C$. elegans protein, F42G9.1, which corresponds to the first ORF from cosmid clone F42G9 sequenced by the $C$. elegans genome sequencing project (Sulston et al., 1992; Wilson et al., 1994). Cosmid F42G9 has been placed on the physical map at the left end of Linkage Group III, close to fem-2 on the eP64 contig, about $100 \mathrm{kbp}$ toward daf-7 (Pilgrim, 1993). (The F42G9 cosmid is colinear with cosmid F10H6 in Figure 5 of Pilgrim, 1993). The sequence identity between FEM-2 and F42G9.1 is restricted to the conserved motifs, suggesting that the two proteins are distantly related (Figure 5). The predicted F42G9.1 product appears to contain a large in-frame insertion between motifs II and III, relative to all the other homologues. Because the transcript from this region has not been examined, it is possible that this represents a cryptic intron.

Figure 5 shows a cartoon of the alignment of the protein homologues. The proteins fall into three structural classes, based on the following criteria: 1) the presence of an extended amino-terminal domain (Class A); 2) the presence of an "Asp-Trp" dipeptide at the end of motif I (Class B and C); and 3) the presence of an extended carboxy terminus and a conserved acidic 9- or 10-amino acid peptide between motifs IV and V (Class C: ILRAEEDEF in the rat PP2C $\beta$ isoform, IERSEEDDQF in the human $\alpha$ isoform, and EALTPEDEF in F42G9.1).

Twelve fem-2 mutant alleles have been isolated and genetically characterized (Kimble et al., 1984; Hodgkin, 1986). Two of the existing alleles are temperature sensitive, and at least four others are thought to have two mutations in the fem-2 gene (Hodgkin, 1986). All of the putative $e 2101$ to $e 2106$ single mutants were isolated in trans to a doubly mutated allele b245e2005 (Hodgkin, 1986). Of these alleles, e2105 has been proposed as a candidate for a null allele (Hodgkin, 1986). However, because homozygous fem-2(e2105) XO animals are completely feminized only at $25^{\circ} \mathrm{C}$, the possibility remains that the e2105 allele retains some low level of Fem-2 activity. The recent isolation of genetic deficiencies for portions of the left end of Linkage Group III $(\mathrm{H}$. Stewart and D. Baillie, personal communication; L. Venolia, personal communication) allowed a more definitive test for a null allele. One of the predicted characteristics of a null allele is that the phenotype of the allele in trans to a deficiency for the locus is no more severe than the phenotype of the homozygous 


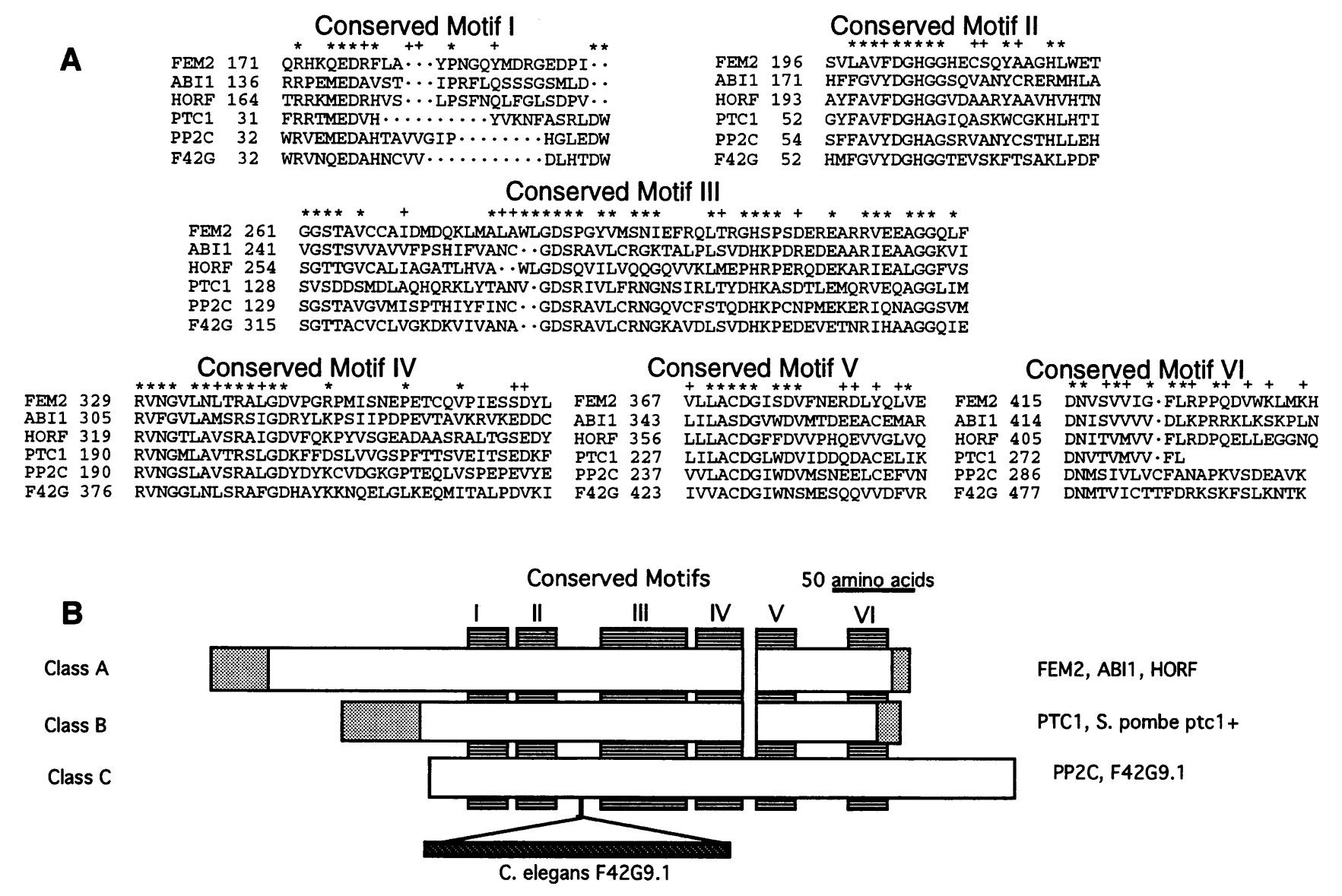

Figure 5. FEM-2 alignment with putative homologues. (A) Alignment of putative homologues to illustrate conserved motifs. Sequences are as follows: FEM2, predicted protein from fem-2 locus; ABI1, ABI1 protein from Arabidopsis thaliana (Leung et al., 1994; Meyer et al., 1994); HORF, predicted human protein from cDNA sequence (Nomura et al., 1993); PTC1, Saccharomyces cerevisiae product of PTC1 gene (Maeda et al., 1993); PP2C, rat protein phosphatase 2C $\beta$ isoform (Wenk et al., 1992); F42G, F42G9.1 ORF from C. elegans sequencing project (Wilson et al., 1994). $*=>, 60 \%$ of proteins have same amino acid $+=>80 \%$ of proteins have one of two amino acids; $\bullet=$ gap introduced to maximize alignment. Numbers refer to the residue number at the beginning of the motif. Other mammalian PP2C homologues are similar to the P2CB sequence. Motifs IV and V are contiguous in FEM-2, ABI1, HORF, and PTC1, but are separated by a 9- to 10-amino acid peptide in the mammalian PP2C homologues and F42G9.1 (ILRAEEDEF in the rat PP2C $\beta$ isoform, IERSEEDDQF in the human $\alpha$ isoform, and EALTPEDEF in F42G9.1). Sequence accession numbers: ABI1, gp X77116; HORF, gp D13640; PTC1, sp P35182; PP2C, sp P35815; and F42G9.1, gp U00051. (B) Alignment of proteins to show relative positions of conserved motifs I-VI. Stippled boxes represent position and extent of the conserved motifs. Open boxes represent protein sequences, shaded boxes represent extensions that are not present in all members of a class. The dark hashed box is the predicted extra sequence in the C. elegans F42G9.1 protein that lies between motifs II and III. Motif IV and V are colinear in Class $\mathrm{A}$ and $\mathrm{B}$ proteins, but separated by a 9- to 10 -amino acid peptide in Class $\mathrm{C}$ proteins. The spacing between motif V and VI varies between the proteins.

null allele. Embryos homozygous for either the $s D f 124$ or $w c D f 1$ deficiencies fail to show a PCR product with two different primers sets from the fem-2 coding region (Figure 6), although primers corresponding to sequences elsewhere in the genome are able to amplify products. Therefore, both deficiencies appear to delete much if not all of the fem-2 gene.

The e2105 allele was placed in trans with a deficiency, and the phenotype of the resulting animals was examined. In the XO, the requirement for Fem-2 activity is least stringent at lower temperatures
(Hodgkin, 1986). At $20^{\circ} \mathrm{C}$, many e2105 XO homozygotes die during development (the animals most often break open due to a weakening in the ventral hypodermis), but a few survive, and they have abnormal gonads, containing oocyte-like cells. These animals also have rudiments of the male tail, with a small fan. Rays are often present (Figure 7; Hodgkin, 1986) and the animals are sterile. At $15^{\circ} \mathrm{C}$, the feminization of $\mathrm{XO}$ animals is weaker (Figure 7). The gonad has a typically female shape, but only rarely are oocyte-like cells seen. These animals also have projections or bulges in the ventral midbody region, where the vulva would 


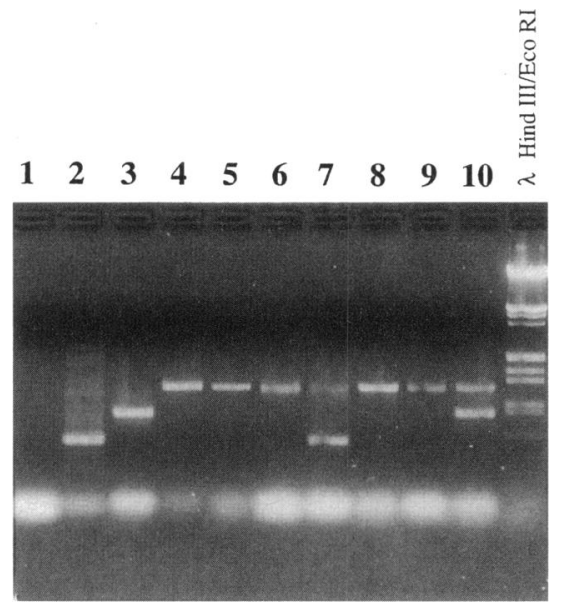

Figure 6. PCR analysis of putative deficiencies for the fem-2 region. DNA was prepared from embryos that were wild type for fem-2 (lanes 1-4, 7, and 10), homozygous for $w c D f 1$ (lanes 5 and 8), or homozygous for $s D f 124$ (lanes 6 and 9). Three primer sets were used to PCR amplify the DNA. Two sets correspond to fem-2 (SAD2DHA19 and DHA4-DHA17) whereas the third set amplifies a region of the unlinked unc-119 gene (MMA1-MMA2). Lane 1 contains one primer from each of the three primer sets (DHA4, MMA1, and SAD2). Lanes 2-4 show the bands amplified for each of the three primer sets alone on wild-type DNA (SAD2-DHA19, DHA4DHA17, and MMA1-MMA2, respectively). Lanes 5-7 show amplified products of two primer sets (SAD2-DHA19 and MMA1MMA2) with $w c D f 1$, wild-type, and $s D f 124$ embryos. Lanes 8-10 show amplified products of the primer sets DHA4-DHA17 and MMA1-MMA2, again with $w c D f 1$, wild-type, and $s D f 124$ embryos. Each lane represents the PCR results from a single embryo.

normally form in a female. The fan and rays in the tail are more wild type. Although the $\mathrm{XO}$ phenotype can vary from animal to animal, the range of feminization seen in hemizygous e2105/Df XO animals is indistinguishable from $e 2105$ homozygotes at either temperature (Figure 7). Identical results were seen with e2105 in trans to either $s D f 124$ or $w c D f 1$. Because one of the tests for a null allele is that the homozygous and hemizygous phenotypes are identical, this suggests that $e 2105$ is a putative null mutation for the fem-2 gene.

The DNA encoding the fem-2 locus (between nucleotide positions 250 and 2650; Figure 3) was sequenced from eight of the mutant fem-2 alleles (b245ts, q117ts, and e2101-6), and from two different strains containing wild-type $\mathrm{fem}-2$ genes. All alleles were reportedly induced using ethylmethane sulfonate (EMS), which causes primarily transition mutations of G-C to A-T bp. Both PCR amplified wild-type alleles showed an identical sequence to that determined from the clones isolated from the genomic and cDNA libraries. All mutant alleles showed base changes when compared with the wild-type sequence. The positions of the mutations in these alleles are shown in Figure 3. The q117ts allele contains a single G-C to A-T base change at position 1242 , which is predicted to cause the substitution of glutamic acid for glycine. The b245ts allele contains a single G-C to A-T change at position 1828, predicted to cause a substitution of arginine for glycine at amino acid 341 in motif IV. This position is absolutely conserved among all homologues shown. The $e 2102$ allele contains a single G-C to A-T change at position 1262, creating an in-frame stop codon.

The $e 2101, e 2103, e 2104, e 2105$, and $e 2106$ sequences were identical to one another, and unexpectedly showed two base changes from wild type. One change was identical to the $b 245$ mutation at position 1828 . The other was a G-C to A-T transition at position 1466, which creates an in-frame stop codon (Figure 3 ). These alleles (along with e2102) were isolated in a noncomplementation screen in a strain containing the b245e2005 double mutation (Hodgkin, 1986). Although the entire DNA sequence from this allele has not been determined, $b 245 e 2005$ also shows the $b 245^{\prime}$ change at position 1828, and the "stop" at position 1466. It therefore appears that the e2101, $-3,-4,-5$, and -6 alleles were not "new" fem-2 alleles, but recombinational reisolates of $b 245 e 2005$. Regardless of their origin, both the presence of a translational stop codon, and the hemizygous phenotype support the contention that these represent the null phenotype of fem-2.

\section{DISCUSSION}

The fem-2 gene product acts in the sex determination hierarchy, as a positive regulator of the male fate (spermatogenesis) in the germ line, and as a negative regulator of the female fate in the soma. If all genes downstream of tra-2 in the epistatic pathway act in a cell autonomous manner, the interactions in the soma can be modeled as a signal transduction pathway, culminating in the TRA-1 transcriptional regulator protein (Figure 1). The genetic epistasis suggests the following: 1) that the tra-2 and tra-3 genes negatively regulate the fem genes, and 2) that the fem genes negatively regulate the activity of tra-1. The activity of all three of the fem genes seems to be required for normal male development, but it is not known how, or if, they interact. FEM-2 may play different regulatory roles in the germ line and in the soma. Loss-of-function (lf) mutations in tra-1 suppress the somatic feminization caused by fem- 2 mutations (Hodgkin, 1986), but Fem- 2 activity is still required for spermatogenesis at $25^{\circ} \mathrm{C}$ (Hodgkin, 1986). fem-3 gain-of-function (gf) mutations suppress the germline feminization caused by a temperature-sensitive fem- 2 mutation, but do not affect the soma (Barton et al., 1987).

The fem-2 locus has been cloned based upon two lines of evidence. First, transgenes that contain the intact coding region for the putative FEM-2 protein are necessary and sufficient to rescue the mutant phenotype in both germline and somatic tissues, in both $\mathrm{XX}$ 


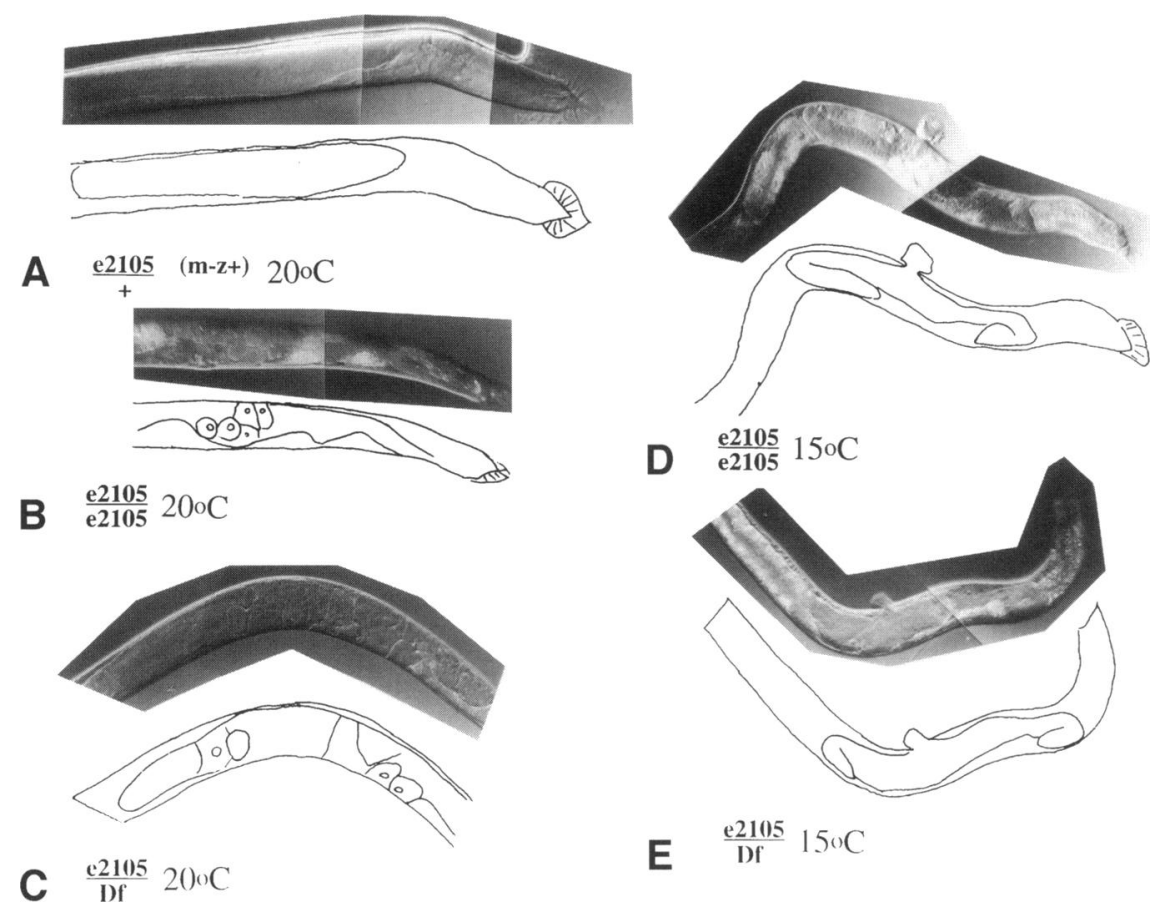

Figure 7. Photographs using differential interference contrast microscopy (top) and cartoons of the photographs (bottom) of the fem-2(e2105) heterozygous, homozygous, and hemizygous $\mathrm{XO}$ phenotypes at different temperatures. All animals were progeny from $\mathrm{fem} / \mathrm{fem}$ mothers. In panels B and C, there are oocyte-like cells apparent in the gonad. The deficiency used in these examples was $s D f 124$, but identical results were seen when $w c D f 1$ was used instead. The XO phenotype can be quite variable, so the examples shown do not portray all the defects seen in animals of the same genotype. Although the tail phenotype is not very clear from these examples, there were no apparent differences in the ranges of defects seen in the homozygous vs. hemizygous animals. and $\mathrm{XO}$ animals. The minimal rescuing region includes $300 \mathrm{bp} 5^{\prime}$ to the predicted translation start codon, and $600 \mathrm{bp} 3^{\prime}$ to the predicted translation termination codon. Second, all mutant alleles of fem-2 that were examined contain base changes within the predicted coding region, compared with two different wild-type alleles as well as to cDNA and genomic DNA clones from the physical mapping project. The base changes are predicted to result in alterations of amino acid sequence in all cases, and are consistent with the mutations resulting from EMS mutagenesis. Two different chromosomal deletions that remove at least part of the predicted fem-2 coding region fail to complement the fem-2(e2105) allele.

The transgenic rescue results with genomic and cDNA clones suggest that a single transcription unit is sufficient to account for all the functions of $f e m-2$ in XX and $X O$ animals. There is a single transcript from the locus in XX animals, which is detected throughout development, but is most abundant in adults. Although this may seem unusual given the masculinizing role of fem-2, and the observation that Fem-2 activity is completely dispensable for adult female development, the fem-2 mutant phenotype can be maternally rescued (only fem-2/fem-2 progeny of fem-2/ fem- 2 mothers are completely feminized), suggesting that the FEM-2 protein or its mRNA can be inherited through the female germ line. The high expression of fem-2 mRNA in the adult hermaphrodite may represent transcription that is restricted to the germ line. Somatic expression of $\mathrm{fem}-2$ is predicted in males throughout their life (Kimble et al., 1984). In mixed male/hermaphrodite cultures, no other transcript has yet been detected.

The sequence similarity found in this work between the predicted FEM-2 protein and protein phosphatase 2C (PP2C) homologues suggests that FEM-2 might have phosphatase activity. PP2C enzymes have been characterized as serine/threonine specific phosphatases that are $\mathrm{Mg}^{+2}$ dependent, and resistant to okadaic acid (Cohen, 1989), but their regulatory role is poorly understood. Maeda et al. (1993 and 1994) showed that the yeast homologue PTC1 is an essential gene in yeast under certain conditions, and suggested that PTC1 is involved in the regulation of a two-component signal transduction system, possibly via a mitogen-activated protein kinase homologue involved in osmosensing. $S$. cerevisiae has at least three separate mitogen-activated protein kinase cascades (reviewed in Nieman, 1993). The mutant phenotypes of genes involved in each separate yeast pathway do not show obvious pleiotropic defects, suggesting that there is little or no interaction between the pathways under normal circumstances. None of the other proteins in these pathways show similarity to any of the gene products in the $C$. elegans sex determination pathway.

Another apparent homologue of FEM-2 is the $A B I 1$ gene of Arabidopsis thaliana. The abi1 mutant is insensitive to the phytohormone abscisic acid (ABA) (Koornneef et al., 1984). ABA is involved in many aspects of plant growth and development. In at least one fern species, ABA-resistant mutations affect sex 
determination (Banks, 1994). The abi1 mutant phenotype in Arabidopsis has been proposed to result from a lack of negative feedback regulation in an intracellular step of hormone signaling (Leung et al., 1994; Meyer et al., 1994). The mutation in the abi1-1 allele affects a conserved glycine in motif II, suggesting a role for this motif in the negative regulation of the phosphatase activity (Leung et al., 1994; Meyer et al., 1994). ABI1 has been shown to have protein phosphatase function in vitro (Leung et al., 1994; Meyer et al., 1994). Again, although FEM-2, PTC1, and $A B I 1$ appear to have roles in the regulation of signal transduction pathways, there is no evidence that any other components in the signaling pathways are common to the systems.

Despite the similarity between FEM-2 and canonical mammalian PP2C enzymes, FEM-2 is most similar in sequence to an unidentified human ORF. With the long amino-terminal domain, short carboxy-terminal domain, and lack of a conserved decapeptide between domains IV and V, FEM-2 (along with $A B I 1$ and the human ORF) appears to fall into a distinct class of PP2C homologues. The presence of the long amino terminal domain suggests that the three proteins may regulate their protein activity in a manner different from the classical PP2C proteins. The Arabidopsis KAPP phosphatase also appears to be a Class A PP2C enzyme, based upon its long amino-terminal domain (320 amino acids; Stone et al., 1994). In this case the amino-terminal domain appears to directly interact with the receptor serine/ threonine kinase RLK5. The F42G9.1 protein from C. elegans is more similar in structure to the canonical mammalian PP2C proteins. F42G9.1 does not have the long amino terminus found in FEM-2 and ABI1, but does have the decapeptide between domains IV and $\mathrm{V}$, which makes it most similar to the mammalian PP2C isoforms. No genetic loci have yet been identified that map to the predicted position of F42G9.1, and the existence of a protein product has not been confirmed.

Could the sex determination pathway be regulated by phosphorylation? There are several well studied paradigms for regulation of transcription by phosphorylation (Hunter and Karin, 1992). For example, the nuclear localization of the transcription factor NF[ $\kappa] \mathrm{B}$ is controlled by the phosphorylation of its regulatory subunit $\mathrm{I}[\kappa] \mathrm{B}$ (Ghosh and Baltimore, 1990). I[ $[\kappa] \mathrm{B}$ contains ankyrin repeats (Haskill et al., 1991), like FEM-1, therefore the localization of TRA-1 may be controlled by interactions with FEM-1 to control somatic sex. FEM-2 may regulate such an interaction by dephosphorylating FEM-1. However, there is no evidence to suggest that FEM-1 and TRA-1 interact, and limited evidence that TRA-1 is always nuclearly localized (D. Zarkower, personal communication). An alternative model is that fem-3 product may be the target. The predicted FEM-3 protein contains several putative casein kinase phosphorylation sites (Ahringer et al., 1992) but it is not known whether any of these are used in vivo or in vitro. In addition, fem-3 gain-of-function mutations have been shown to suppress the fem-2 phenotype of the conditional allele b245 in the germ line, but not the soma (Barton et al., 1987). These gain-of-function mutations alter a control sequence in the fem-3 3'-untranslated region (UTR) of the mRNA (Ahringer and Kimble, 1991; Evans et al., 1992). Perhaps FEM-2 is a molecule that normally controls fem-3 translation in the germ line, possibly by de-phosphorylating an unidentified untranslated region binding factor. The suppression has only been seen for one allele of fem-2, and is limited to the germ line and therefore, this model does not explain all the observations. A third possibility is that the TRA-1 protein, which has several putative phosphorylation sites, is the target (Zarkower and Hodgkin, 1992). In this model, there must be a second target in the germ cells, where fem-2 activity is normally required and is independent of tra-1. Because fem-2 has different genetic roles in the germ line and soma, neither of these speculations can be ruled out.

A further complication to these models is the absence of a characterized kinase in the sex determination pathway. Because fem-2 mutants show defects in sex determination in both the germ line and soma, one might expect that an associated kinase must exist in the two tissues. If the activity of FEM-2 is to remove phosphate groups from a protein target to produce the "male" phenotype, a protein kinase must initially phosphorylate the target. No kinase has been found among the genes of the pathway; if an associated kinase exists, loss-of-function mutations in the gene are either rare, or do not lead to a simple sexual transformation phenotype (the predicted phenotype of such a mutation would be "Tra" phenotype of masculinization). Perhaps the kinase is constitutive, and essential, or redundant. Alternatively, one of the characterized genes in the pathway may have a kinase activity that cannot be predicted from the primary sequence.

Finally, it is clear that under some circumstances, the FEM-2 product is dispensable for normal male development. There is evidence from the current work that the strongest alleles of fem-2 completely eliminate FEM-2 activity. The sequence of the $e 2102$ and $e 2105$ alleles predicts a truncated protein, missing much of the PP2C conserved region. The phenotype of the $e 2105$ allele gets no stronger when in trans to a deficiency, suggesting that there is no partial function supplied by one copy of $e 2105$. Yet in fem-2(e2105) animals, male somatic structures as well as sperm can still be formed in certain conditions (this work; Hodgkin, 1986). Therefore, C. elegans can bypass the requirement for fem-2 activity. If FEM-2 is a phosphatase whose activity leads to 
the activation of spermatogenesis and the inactivation of TRA-1 in the soma, such dephosphorylation is not an essential part of the regulation. Identification of the cellular targets of FEM-2 activity will help to clarify its apparent dual role in somatic and germline sex determination.

\section{ACKNOWLEDGMENTS}

We thank those who generously shared their unpublished materials with us. fem-2(q117ts) was a gift from J. Kimble. Some strains used in this work were provided by the C. elegans Genetic Toolkit Project, funded by the National Institutes of Health, National Center for Research Resources. The balancer $s C 1$ and strain $\mathrm{BC} 4330$ containing $s D f 124$ were gifts from $\mathrm{H}$. Stewart and D. Baillie. D. Baillie also helped with the initial search of the sequence databases. $w c D f 1$ was a gift from L. Venolia. The cDNA library was generously provided by B. Barstead. We thank R. Hodgetts and J. Rothman and anonymous reviewers for critical reading of the manuscript, and R. Simpson for technical help. This work was supported by grants from the Natural Sciences and Engineering Research Council and the Alberta Heritage Fund for Medical Research. A small part of this work was carried out by D.P. at the MRC Laboratory of Molecular Biology in Cambridge, U.K., where he was a recipient of a Human Frontiers Science Program Postdoctoral Fellowship.

\section{REFERENCES}

Ahringer, J., and Kimble, J. (1991). Control of the sperm-oocyte switch in Caenorhabditis elegans hermaphrodites by the fem-3 3'untranslated region. Nature 349, 346-348.

Ahringer, J., Rosenquist, T.A., Lawson, D.N., and Kimble, J. (1992). The Caenorhabditis elegans sex-determining gene fem-3 is regulated post-transcriptionally. EMBO J. 11, 2303-2310.

Altschul, S.F., Gish, W., Miller, W., Myers, E.W., and Lipman, D.J. (1990). Basic local alignment search tool. J. Mol. Biol. 215, 403-410.

Banks, J.A. (1994). Sex-determining genes in the homosporous fern Ceratopteris. Development 120, 1949-1958.

Barstead, B., and Waterston, B. (1989). The basal component of the nematode dense-body is vinculin. J. Biol. Chem. 264, 10177-10185.

Barton, M.K., Schedl, T.B., and Kimble, J. (1987). Gain-of-function mutations of fem-3, a sex-determination gene in Caenorhabditis elegans. Genetics 115, 107-119.

Broverman, S.A., and Meneely, P.M. (1994). Meiotic mutants that cause a polar decrease in recombination on the $X$ chromosome in Caenorhabditis elegans. Genetics 136, 119-127.

Clifford, R., Francis, R., and Schedl, T. (1994). Somatic control of germ cell development in Caenorhabditis elegans. Semin. Dev. Biol. 5, 21-30.

Cohen, P. (1989). The structure and regulation of protein phosphatases. Annu. Rev. Biochem. 58, 453-508.

Coulson, A., Kozono, Y., Lutterbach, B., Shownkeen, R., Sulston, J., and Waterston, R. (1991). YACs and the C. elegans genome. BioEssays $13,413-417$.

Coulson, A., Sulston, J., Brenner, S., and Karn, J. (1986). Toward a physical map of the genome of the nematode C. elegans. Proc. Nat. Acad. Sci. USA 83, 7821-7825.

Coulson, A., Waterston, R., Kiff, J., Sulston, J., and Kohara, Y. (1988). Genome linking with yeast artificial chromosomes. Nature 335, 184-186.

DeLong, L., Plenefisch, J.D., Klein, R.D., and Meyer, B.J. (1993). Feedback control of sex determination by dosage compensation revealed through Caenorhabditis elegans sdc-3 mutations. Genetics 133, 875-896.

Doniach, T., and Hodgkin, J. (1984). A sex-determining gene, fem-1, required for both male and hermaphrodite development in Caenorhabditis elegans. Dev. Biol. 106, 223-235.

Evans, T.C., Goodwin, E.B., and Kimble, J. (1992). Translational regulation of development and maternal RNAs in Caenorhabditis elegans. Semin. Dev. Biol. 3, 381-389.

Frohman, M.A., Dush, M.K., and Martin, G.R. (1988). Rapid production of full-length cDNAs from rare transcripts: amplification using a single gene-specific oligonucleotide primer. Proc. Nat. Acad. Sci. USA 85, 8998-9002.

Ghosh, S., and Baltimore, D. (1990). Activation in vitro of NF- $[\kappa]$ B by phosphorylation of its inhibitor I[ $\kappa] B$. Nature 344, 678-682.

Graham, P.L., and Kimble, J. (1993). The mog-1 gene is required for the switch from spermatogenesis to oogenesis in Caenorhabditis elegans. Genetics 133, 919-931.

Haskill, S., Beg, A.A., Tomkins, S.M., Morris, J.S., Yurochko, A.D., Sampson-Johannes, A., Mondal, K., Ralph, P., and Baldwin, A.S. (1991). Characterization of an immediate-early gene induced in adherent monocytes that encodes I[ $\kappa] B$-like activity. Cell $65,1281-$ 1289.

Hodgkin, J. (1986). Sex determination in the nematode C. elegans: analysis of tra-3 suppressors and characterization of fem genes. Genetics 114, 15-52.

Hodgkin, J. (1990). Sex determination compared in Drosophila and Caenorhabditis. Nature 344, 721-728.

Hodgkin, J. (1992). Genetic sex-determining mechanisms and evolution. BioEssays 14, 253-261.

Hodgkin, J.A. (1980). More sex determination mutants of Caenorhabditis elegans. Genetics 96, 649-664.

Hodgkin, J.A. (1987). Primary sex determination in the nematode Caenorhabditis elegans. Development 101(suppl), 5-16.

Hodgkin, J.A., and Brenner, S. (1977). Mutations causing transformation of sexual phenotype in the nematode Caenorhabditis elegans. Genetics 86, 275-287.

Hope, I.A. (1994). PES-1 is expressed during early embryogenesis in Caenorhabditis elegans and has homology to the fork head family of transcription factors. Development 120, 505-514.

Hunter, C.P., and Wood, W.B. (1992). Evidence from mosaic analysis of the masculinizing gene her-1 for cell interactions in C. elegans sex determination. Nature 355, 551-555.

Hunter, T., and Karin, M. (1992). The regulation of transcription by phosphorylation. Cell 70, 375-387.

Kimble, J., Edgar, L., and Hirsh, D. (1984). Specification of male development in Caenorhabditis elegans: the fem genes. Dev. Biol. 105, 234-239.

Koornneef, M., Reuling, G., and Karssen, C.M. (1984). The isolation and characterization of abscisic acid-insensitive mutants of Arabidopsis thaliana. Physiol. Plant. 61, 377-383.

Krause, M., and Hirsh, D. (1987). A trans-spliced leader sequence on actin mRNA in C. elegans. Cell 49, 753-761.

Kuwabara, P.E., and Kimble, J. (1992). Molecular genetics of sex determination in C. elegans. Trends Genet. 8, 164-168.

Kuwabara, P.E., Okkema, P.G., and Kimble, J. (1992). tra-2 encodes a membrane protein and may mediate cell communication in the Caenorhabditis elegans sex determination pathway. Mol. Biol. Cell 3, 461-473.

Leung, J., Bouvier-Durand, M., Morris, P.C., Guerrier, D., Chefdor, F., and Giraudat, J. (1994). Arabidopsis ABA-response gene ABI1: 
features of a calcium-modulated protein phosphatase. Science 264, $1448-1452$.

Maeda, T., Tsai, A.Y.M., and Saito, H. (1993). Mutations in a protein tyrosine phosphatase gene $(P T P 2)$ and a protein serine/threonine phosphatase gene (PTC1) cause a synthetic growth defect in Saccharomyces cerevisiae. Mol. Cell. Biol. 13, 5408-5417.

Maeda, T., Wurgler-Murphy, S.M., and Saito, H. (1994). A twocomponent system that regulates an osmosensing MAP kinase cascade in yeast. Nature $369,242-245$.

Mello, C.C., Kramer, J.M., Stinchcomb, D., and Ambros, V. (1991). Efficient gene transfer in C. elegans: extrachromosomal maintenance and integration of transforming sequences. EMBO J. 10, 3959-3970.

Meyer, K., Leube, M.P., and Grill, E. (1994). A protein phosphatase $2 \mathrm{C}$ involved in ABA signal transduction in Arabidopsis thaliana. Science 264, 1452-1455.

Miller, L.M., Plenefisch, J.D., Casson, L.P., and Meyer, B.J. (1988). xol-1: a gene that centrols the male modes of both sex determination and $X$ chromosome dosage compensation in C. elegans. Cell 55, 167-183.

Nieman, A.M. (1993). Conservation and reiteration of a kinase cascade. Trends Genet. 9, 390-394.

Nigon, V. (1951). Polploidie expérimentale chez un nématode libre, Rhabditis elegans Maupas. Biol. Bull. Fr. et Belg. 95, 187-225.

Nomura, N., Miyajima, N., Kawarabayashi, Y., and Tabata, S. (1993). Prediction of new human genes by entire sequencing of randomly sampled cDNA clones. GenBank accession number D13640.

Nusbaum, C., and Meyer, B.J. (1989). The Caenorhabditis elegans gene $s d c-2$ controls sex determination and dosage compensation in $\mathrm{XX}$ animals. Genetics 122, 579-593.

Perry, M.D., Li, W., Trent, C., Robertson, B., Fire, A., Hageman, J.M., and Wood, W.B. (1993). Molecular characterization of the her-1 gene suggests a direct role in cell signaling during Caenorhabditis elegans sex determination. Genes Development 7, 216-228.

Pilgrim, D. (1993). The genetic and RFLP characterization of the left end of linkage group III in Caenorhabditis elegans. Genome 36, 712724.

Pilgrim, D.B., and Bell, J.B. (1993). Expression of a Drosophila melanogaster amber suppressor tRNASer in Caenorhabditis elegans. Mol. Gen. Genet. 241, 26-32.
Rosenquist, T.A., and Kimble, J. (1988). Molecular cloning and transcript analysis of fem-3, a sex-determining gene in Caenorhabditis elegans. Genes Development 2, 606-616.

Sambrook, J., Fritsch, E.F., and Maniatis, T. (1989). Molecular Cloning: A Laboratory Manual, 2nd ed., Cold Spring Harbor, NY: Cold Spring Harbor Laboratory Press.

Schedl, T., and Kimble, J. (1988). fog-2, a germ-line-specific sexdetermining gene required for hermaphrodite spermatogenesis in Caenorhabditis elegans. Genetics 119, 43-61.

Spence, A.M., Coulson, A., and Hodgkin, J. (1990). The product of fem-1, a nematode sex-determining gene, contains a motif found in cell cycle control proteins and receptors for cell-cell interactions. Cell 60, 981-990.

Stone, J.M., Collinge, M.A., Smith, R.D., Horn, M.A., and Walker, J.C. (1994). Interaction of a protein phosphatase with an Arabidopsis serine-threonine receptor kinase. Science 266, 793-795.

Sulston, J., et al. (1992). The C. elegans genome sequencing project: a beginning. Nature 356, 37-41.

Villeneuve, A.M., and Meyer, B.J. (1987). sdc-1: a link between sex determination and dosage compensation in C. elegans. Cell 48, 2537.

Wenk, J., Trompeter, H.I., Pettrich, K.G., Cohen, P.T., Campbell, D.G., and Mieskes, G. (1992). Molecular cloning and primary structure of a protein phosphatase 2C isoform. FEBS Lett. 297, 135-138.

Williams, B.D., Schrank, B., Huynh, C., Shownkeen, R., and Waterston, R.H. (1992). A genetic mapping system in Caenorhabditis elegans based on polymorphic sequence-tagged sites. Genetics 131, 609624 .

Wilson, R., et al. (1994). 2.2 Mb of contiguous nucleotide sequence from chromosome III of $C$. elegans. Nature 368, 32-38.

Wood, W.B. (ed.) and the community of C. elegans researchers. (1988). The nematode Caenorhabditis elegans, vol. 17, Cold Spring Harbor monograph series, 17.

Zarkower, D., and Hodgkin, J. (1992). Molecular analysis of the $C$. elegans sex-determining gene tra-1: a gene encoding two zinc finger proteins. Cell 70, 237-249. 